\title{
Damian Kokoć
}

Uniwersytet Adama Mickiewicza w Poznaniu

\section{PROBLEM ISTNIENIA W FILOZOFII GRECKIEJ (UJĘCIE CHARLESA H. KAHNA) $^{1}$}

Badacze myśli antycznej i metafizyki klasycznej zgodnie uznają, że problematyka istnienia była pomijana przez Greków². Wynikało to przede wszystkim ze sposobu, w jaki antyczni postrzegali świat, a który znalazł swój wyraz zarówno w sferze mitów, jak i namysłu filozoficznego. Jak zauważa Jacek Wojtysiak, antyczni Hellenowie postrzegali świat jako względnie przygodny, czyli uznawali, że istnienie kosmosu jest czymś koniecznym. Natomiast to, jaki on jest, już takie nie jest, gdyż rzeczywistość podlega ciągłym przemianom. Dlatego też niewykluczone jest, że świat mógł przyjąć inną formę, tak jak rządzące nim prawa. Natomiast nie rozpatrywali rzeczywistości jako radykalnie przygodnej, czyli przyj-

${ }^{1}$ Niniejszy artykuł stanowi zmodyfikowaną część pierwszego rozdziału mojej rozprawy doktorskiej Istota i istnienie w filozofii muzutmańskiej. Koncepcje Awicenny oraz Awerroesa $i$ ich recepcja w myśli Tomasza z Akwinu, obronionej w listopadzie 2015 roku w Instytucie Filozofii Uniwersytetu im. Adama Mickiewicza w Poznaniu.

2 Zob. É Gilson, Byt i istota, tłum. D. Eska, J. Nowak, Warszawa 20o6; M. A. Krąpiec, Struktura bytu. Charakterystyczne elementy systemu Arystotelesa $i$ Tomasza z Akwinu, Lublin 200o; M. A. Krąpiec, Byt i istota. Św. Tomasz „De ente et essentia” przektad i komentarz, Lublin 2001; P. Milcarek, Od istoty do istnienia. Tworzenie się metafizyki egzystencjalnej wewnątrz tacińskiej tradycji filozofii chrześcijańskiej, Warszawa 2008; E. Morawiec, P. Mazanka, Metafizyka klasyczna wersji egzystencjalnej. Podstawowe zagadnienia z metafizyki, Warszawa 2006; E. Morawiec, Odkrycie egzystencjalnej wersji metafizyki klasycznej. Studium historyczno-analityczne, Warszawa 2004; J. Wojtysiak, O stowie BYĆ. Z teorii wyrażeń egzystencjalnych i ich filozoficznego zastosowania, Lublin 2005 . 
mowali, że wszechświat jest czymś wiecznym, i nie uznawali, że mogłoby go w ogóle nie być ${ }^{3}$. Taka wizja świata powodowała, że Grecy koncentrowali się przede wszystkim na próbie odpowiedzi na pytanie o naturę rzeczywistości: co stanowi jej podstawowy budulec i co decyduje o tym, że kosmos jest taki, jaki jest. Sytuacja ta uległa zmianie w momencie zetknięcia się filozofii greckiej z koncepcjami kosmologicznymi religii abrahamowych. Oparte na idei creatio ex nihilo, podkreślały one, że to Bóg, kierując się tylko swoją wolą i wszechmocą, powołał wszystko do istnienia z niczego. Jak zauważa Ernst Tugendhat: „Wszakże filozofia dopiero wtedy zauważyła «...jest...», gdy uderzyło ją «nie jest...»"4. Dlatego dopiero filozofowie żydowscy, chrześcijańscy i muzułmańscy zaczęli zadawać pytania nie tylko o istotę, ale też o istnienie wszystkiego, co jest. Warto podkreślić, że prekursorami w systematycznym podejmowaniu problemu istnienia i jego relacji do istoty byli nie chrześcijanie, ale uczeni muzułmańscy.

Duże znaczenie w badaniach nad antycznymi koncepcjami bytu, w tym również nad podejściem filozofii greckiej do problemu istnienia, mają niewątpliwie rozważania Charlesa H. Kahna. Filozof ten, opierając się na analizie języka, którym operowali starożytni myśliciele helleńscy, wyjaśnia, dlaczego kwestia istnienia nie była przez nich podejmowana lub też traktowana była marginalnie. Kahn twierdzi, że kluczowym zagadnieniem w teoriach bytu, jakie stworzyli Grecy, nie było pojęcie istnienia, ale znaczenie prawdziwościowe czasownika einai. Badania filologiczne są w tym przypadku o tyle uzasadnione, że - jak zauważa - to, jak ujmujemy otaczającą nas rzeczywistość, jest w dużym stopniu uzależnione od języka, którym się posługujemy. Dotyczy to również rozważań ontologicznych.

${ }^{3}$ J. Wojtysiak, Starożytne początki problematyki istnienia, „Kwartalnik Filozoficzny” 29 (2001) nr 1, s. 5-27; D. Kokoć, Creatio ex nihilo a filozoficzne wyodrębnienie problematyki istnienia, „Przegląd Religioznawczy” 251 (2014) nr 1, s. 55-64.

${ }^{4}$ E. Tugendhat, Bycie i Nic, w: E. Tugendhat, Bycie. Prawda. Rozprawy filozoficzne, tłum. J. Sidorek, Warszawa 1999, s. 35-36. 
Jako przykład najbardziej wyraźnego użycia omawianego czasownika w filozofii antycznej Kahn podaje słyną maksymę Protagorasa: „Człowiek jest miarą wszystkich rzeczy, tego, co jest, że jest, tego, czego nie ma, że nie ma" (DK 8o A 1) $)^{5}$. Już sama konstrukcja tego zdania nasuwa jego interpretację egzystencjalną. Jednak można wskazać na dwie trudności, które przeczą takiemu odczytaniu tej sentencji. Po pierwsze zdaniem tego współczesnego uczonego Protagoras chce tutaj powiedzieć, że człowiek jest miarą ${ }^{6}$ nie tylko i wyłącznie dla istnienia, ale dla każdej rzeczy, w tym także dla tego, co możliwe. Frederick Copleston i Giovanni Reale podają, że niektórzy badacze doszukują się w tej wypowiedzi Protagorasa antycypacji poglądów Immanuela Kanta. Mówiąc o człowieku jako mierze prawdziwości sądów, miał on mieć na myśli człowieka jako gatunek, a nie indywiduum ${ }^{7}$. Drugi zarzut, jaki formułuje Kahn, oparty jest na rozważaniach Platona, który do objaśnienia słów tego sofisty wykorzystuje konstrukcję orzecznikową. Ma to świadczyć o tym, że nie można sprowadzać wypowiedzi filozofa z Abdery tylko do znaczenia egzystencjalnego. Nawet jeśli uznamy, że interpretacja Platona jest błędna, to i tak ukazuje to, że w umysłowości greckiej użycie einai w konstrukcji absolutnej nie musiało oznaczać jego egzystencjalnego charakteru, ale np. można je odczytywać jako „jest tak oto” lub „zachodzi”.

${ }^{5}$ Ch. H. Kahn, O czasowniku „być” i pojęciu bytu w grece, w: Ch. H. Kahn, Język i ontologia, tłum. B. Żukowski, Kęty 2008, s. 14. W polskim tłumaczeniu Historii filozofii starożytnej Realego oraz Żywotach i poglądach stynnych filozofów Diogenesa Laertiosa zdanie to oddane jest w taki sposób, który skłania do jego egzystencjalnej interpretacji: „Człowiek jest miarą wszystkich rzeczy, istniejących, że istnieją, i nie istniejących, że nie istnieją". Zob. G. Reale, Historia filozofii starożytnej, t. 1, tłum. E. I. Zieliński, Lublin 2ooo, s. 247, Diogenes Laertios, Żywoty i poglądy stynnych filozofów, tłum. I. Krońska i in., Warszawa 2004, s. 545 (IX, 51).

${ }^{6}$ Czyli, jak zauważa Reale, źródłem norm prawdziwości dla wypowiadanych sądów. Natomiast przez „rzecz” ten grecki filozof miał rozumieć wszelkie fakty. Zob. G. Reale, Historia..., t. 1, dz. cyt., s. 247.

7 Zob. F. Copleston, Historia filozofii, t. 1, tłum. H. Bednarek, Warszawa 1998, s. 106; G. Reale, Historia..., t. 1, dz. cyt., s. 248. 
Jeśli chodzi o najbardziej pierwotne użycie czasownika „być” w języku greckim, to Kahn wskazuje właśnie na jego zastosowanie w znaczeniu prawdziwościowym. Dlatego też rozważania ontologiczne antycznych filozofów korespondują ze sposobem, w jaki postrzegali oni wszechświat. To, w jaki sposób o nim mówią, miało oddawać to, jaki on jest naprawdę. Znajduje to odbicie w tym, jak definiowali prawdę: „mówić o rzeczach, które są (faktem), że są, a o rzeczach, których nie ma, że ich nie ma" ${ }^{8}$. Konsekwencją takiego podejścia jest to, że w każdym zdaniu o konstrukcji orzecznikowej, w którym stwierdzamy zajście jakiegokolwiek faktu za pomocą czasownika „być”, zawiera się w tym czasowniku sens prawdziwościowy. Przechodząc na grunt rozważań czysto filozoficznych: gdy Grecy używali einai w formie samodzielnej, to według współczesnego uczonego nie nadawali temu czasownikowi wymiaru egzystencjalnego, ale rozumieli go jako „być tak oto”, „zachodzić” albo „być prawdą”. Zdaniem Arystotelesa najbardziej precyzyjny sens „być” kryje się właśnie w jego znaczeniu prawdziwościowym. Kahn podkreśla, że Stagiryta dostrzegał takie znaczenie nawet w konstrukcjach orzecznikowych ${ }^{9}$. Dla potwierdzenia tego można podać fragment z Metafizyki, gdzie Arystoteles stwierdza: „Dalej, «istnienie» i «jest» znaczy, że twierdzenie jest prawdziwe, a «nie-istnienie», że jest nie prawdziwe, lecz fałszywe, i tak samo w przypadku twierdzenia i przeczenia"10. Dalej Stagiryta podaje przykłady takich zdań orzecznikowych jak „Sokrates jest wykształcony” - jako zdania prawdziwego i „przekątna kwadratu nie jest wymierna z bokiem" - jako zdania fałszywego ${ }^{11}$.

Kahn konstatuje, że położenie nacisku na prawdziwościowe znaczenie czasownika „być” powodowało, że w teoriach, jakie stworzyli Parmenides czy Platon, pojęcie bytu odnoszone jest głównie do pojęcia rzeczywistości oraz odpowiadającego mu pojęcia prawdy. Pytanie

${ }^{8}$ Ch. H. Kahn, O czasowniku..., dz. cyt., s. 19.

9 Zob. Ch. H. Kahn, O czasowniku..., dz. cyt., s. 16-2o.

${ }^{10}$ Arystoteles, Metafizyka, w: Arystoteles, Dzieła wszystkie, t. 2, tłum. K. Leśniak, Warszawa 2003, s. 694 (1017 a).

11 Zob. Arystoteles, Metafizyka, dz. cyt., s. 694 (1017 a). 
o byt jest tak naprawdę pytaniem o strukturę i istotę świata, jaka ona musi być, aby możliwe było poznanie prawdziwe bytu. Stało to jego zdaniem u początku wszelkiego namysłu ontologicznego, jaki wykształcił się na gruncie greckiej filozofii antycznej, dlatego też Kahn stwierdza:

W terminologii lingwistycznej oznacza to, że kluczową rolę w powstaniu greckiej ontologii odgrywa to użycie czasownika, które określam mianem zastosowania prawdziwościowego - w którym czasownik esti znaczy „jest prawdą" lub „zachodzi” ${ }^{12}$.

Wydobycie pierwszoplanowej roli znaczenia prawdziwościowego czasownika „być” pozwala odeprzeć oskarżenia, jakie czasami stawia się Parmenidesowi i Platonowi. Myślicielom tym zarzucano, że w swoich rozważaniach nie rozróżniali zastosowania łącznikowego i egzystencjalnego słowa „być”. W kontekście ustaleń Kahna zarzut ten jest bezpodstawny, gdyż zarówno użycie łącznikowe, jak i egzystencjalne są według niego typami zastosowania prawdziwościowego, więc nie można tu mówić o zaciemniającym mieszaniu obu rodzajów zastosowania, bo ostatecznie oba dają się sprowadzić do innego, pierwotniejszego wobec nich użycia. Takie rozumienie tego czasownika powoduje, że to właśnie znaczenie prawdziwościowe einai stanowi podstawę dla ontologii, które powstały na gruncie antycznej filozofii greckiej. Byt jest pojmowany w kategoriach prawdziwości, rozumiany jako coś, o czym można wygłosić prawdziwy sąd ${ }^{13}$.

Uświadomienie sobie, że dla filozofów greckich byt pojmowany był w kontekście jego prawdziwości i faktyczności, stanowi warunek zrozumienia ontologii Platona, Arystotelesa czy też Plotyna. Kahn podkreśla, że „to on” jest dla tych filozofów „przede wszystkim przedmiotem prawdziwej wiedzy i fundamentem lub korelatem prawdziwej wypowiedzi"14.

${ }^{12}$ Ch. H. Kahn, Dlaczego w filozofii greckiej nie pojawia się odrębne pojęcie istnienia?, w: Ch. H. Kahn, Jezzyk i ontologia, dz. cyt., s. 58.

${ }_{13}$ Zob. Ch. H. Kahn, Dlaczego w filozofii greckiej..., dz. cyt., s. 58-59.

${ }^{14}$ Ch. H. Kahn, O czasowniku..., dz. cyt., s. 28. 
Natomiast według greckich filozofów tym, co jest przedmiotem poznania i o czym można prawdziwie coś powiedzieć, jest to, co ma miejsce, w sensie: to, co zaszło, czyli fakt czy relacja, a nie konkretna rzecz. Tutaj zaznacza się według niego główna różnica między antyczną koncepcją bytu a nowożytnymi ujęciami istnienia. W teoriach współczesnych istnienie wiązane jest właśnie z czymś jednostkowym, z konkretnymi rzeczami czy ludźmi, a nie z relacjami, faktami czy sądami. Kahn zauważa, że terminologia ontologiczna, którą posługiwali się antyczni filozofowie, powodowała, że istnienie było przez nich traktowane jako szczególnego rodzaju „zachodzenie stanów rzeczy”"15. Dystynkcje w oddawaniu czasownika einai na „zachodzi”, „istnieje”, „ma miejsce” lub „występuje” zostały wykształcone z biegiem czasu. Dla samych Greków w okresie starożytności były to odmienne zastosowania jednego i tego samego czasownika. Pojawia się on również w funkcji łącznikowej ${ }^{16}$, dlatego też antyczni Grecy nie odróżniali użycia czasownika „być” w znaczeniu egzystencjalnym, łącznikowym lub prawdziwościowym. Same zdania o charakterze egzystencjalnym według Kahna nie miały za swój przedmiot istnienia jako takiego, ale był nim jakiś konkret, podmiot, który spełnia określony predykat, który jest o nim orzekany ${ }^{17}$.

Tym, co charakterystyczne w rozważaniach filozoficznych antycznych Hellenów, jest również to, że występuje w nich silny związek pomiędzy istnieniem a funkcją lokatywną czasownika „być”. Mimo takiej relacji nie można mówić, że są one ze sobą tożsame. Wzajemne powiązanie między nimi ma zdaniem Kahna wynikać z tego, że dla myślicieli greckich jedno znaczenie implikowało drugie i vice versa, a to oznacza, że były one postrzegane jako logicznie równoważne. Powoduje to, że „być” obok znaczenia prawdziwościowego zawierało również znacze-

${ }^{15}$ Zob. Ch. H. Kahn, O czasowniku..., dz. cyt., s. 29.

${ }^{16} \mathrm{Na}$ temat relacji między użyciem czasownika „byćc w znaczeniu łącznikowym i egzystencjalnym zob. Ch. H. Kahn, O terminologii na oznaczenie „kopuli” oraz „istnienia", w: Ch. H. Kahn, Język i ontologia, dz. cyt., s. 34-53.

${ }^{17}$ Zob. Ch. H. Kahn, Z powrotem do teorii czasownika "Być" i pojęcia bytu, w: Ch. H. Kahn, Język i ontologia, dz. cyt., s. 102-103. 
nie lokacyjne. Mówiąc, że coś „jest”, greccy filozofowie mówili nie tylko, że to coś jest prawdziwe, ale też, że znajduje się "gdzieś". Takie użycie omawianego czasownika powodowało, że Parmenides, opisując byt, charakteryzował go jako coś, co znajduje się gdzieś i ma kształt przypominający idealną kulę ${ }^{18}$. Również świat idei Platona, mimo że ze swej natury transcendentny, w opisach nabiera charakteru przestrzeni, która poprzez swoją inteligibilność przeciwstawia się rzeczywistości zmysłowej. W Uczcie pojawia się np. metafora drogi, którą adept w „szkole Erosa" musi przebyć, aby ujrzeć piękno samo w sobie ${ }^{19}$.

Zaznaczone na wstępie niniejszego artykułu postrzeganie wszechświata jako wiecznego spowodowało, że klasyczny język grecki nie wykształcił odrębnego czasownika, który oznaczałby „istnieć”, a dla wyrażenia sądów egzystencjalnych Grecy musieli posługiwać się ogólnym pojęciem „być”, które - jak zostało pokazane wyżej - może przyjąć wiele odcieni znaczeniowych, a dla samych Greków znaczenie egzystencjalne nie było pierwszorzędne. Nie oznacza to, że problematyka istnienia była zupełnie obca filozofom helleńskim, jednak zagadnienie to nigdy nie znajdowało się w centrum ich zainteresowania, a istnienie w sensie absolutnym, jako istnienie samo w sobie, zdaniem wielu badaczy nigdy nie zostało podjęte jako problem filozoficzny. Co nie oznacza, że pewne intuicje dotyczące problemu istnienia i jego relacji do istoty nie pojawiały się w myśli helleńskiej. Przykładem może być fragment z Analityk wtórych Arystotelesa, który stał się jedną z inspiracji do późniejszych rozważań nad relacją pomiędzy istotą a istnieniem. Stagiryta stwierdza w nim:

Jeżeli jednak ma się udowodnić istotę rzeczy i jej istnienie, jak można tego dokonać przy pomocy tego samego argumentu? Wszak definicja przedstawia jakąś jedną rzecz, a tak samo dowód; a pr ze ci i ż is to -

18 Zob. Parmenides, Fragmenty „O naturze”, tłum. M. Wesoły, w: Człowiek i spoŁeczeństwo w refleksji filozoficznej, red. G. Kotlarski, R. Kozłowski, Poznań 1992, s. 235 (DK 28 B 8, 29-30; DK 28 B 8, 42-45).

19 Zob. Platon, Uczta, tłum. W. Witwicki, Warszawa 1999 s. 108 i n. (210 e i n.). 
ta człowieka i fakt jego istnienia to dwie różne rzec zy [podkr. DK] $]^{20}$.

Jednak dystynkcja, o której pisze Arystoteles, ma charakter czysto myślny, zachodzi ona na poziomie logicznym i pojęciowym. Natomiast realnie oba składniki bytu - istota i istnienie - są według Stagiryty ze sobą tożsame ${ }^{21}$. Pierwsze próby systematyzacji tego problemu pojawiły się dopiero w okresie hellenistycznym. Przyczynkiem do tego są rozważania dotyczące ludzkiej wiedzy na temat Boga. Kahn stwierdza:

To ostatnie [rozróżnienie między istotą a istnieniem] systematyczną postać uzyskało po raz pierwszy na gruncie filozofii hellenistycznej, w kontekście wiedzy o Bogu - w swej standardowej formule rozróżnienie to zakłada możliwość wiedzy o istnieniu Boga, lecz wyklucza możliwość poznania jego istoty ${ }^{22}$.

Najstarsze zachowane świadectwa dotyczące tego zagadnienia zdaniem tego uczonego wywodzą się wprawdzie nie z kręgów pogańskich, ale od myślicieli, którzy łączyli dorobek helleński z judeochrześcijańskimi ideami teologicznymi. Sam Kahn wskazuje na żydowskiego myślicie-

${ }^{20}$ Arystoteles, Analityki wtóre, w: Arystoteles, Dzieła wszystkie, t. 1, tłum. K. Leśniak, Warszawa 2003, s. 310 (92 b).

${ }^{21}$ Stanisław Adamczyk stwierdza jednak, że w przypadku myśli Arystotelesa można mówić o realnym charakterze różnicy między istotą a istnieniem. Jego zdaniem fakt przyjęcia przez większość badaczy, że Stagiryta uznawał, iż między tymi składnikami bytu mamy do czynienia tylko z różnicą myślną, wynika z apriorycznego założenia, które ci uczeni przyjmują. Uznają oni, że skoro Arystoteles umieścił ten fragment w swoim piśmie logicznym, to i sama dystynkcja ma wymiar czysto logiczny. Por. S. Adamczyk, Arystotelesowo-tomistyczna koncepcja formy substancjalnej, „Roczniki Filozoficzne” 12 (1964) nr 3, s. 5-15; S. Adamczyk, Różnica między istotą a istnieniem substancjalnym $w$ nauce Arystotelesa, "Roczniki Filozoficzne” 7 (1959) nr 1, s. 103-127; S. Adamczyk, Struktura bytu przygodnego wedtug Arystotelesa (uwagi na marginesie "Struktury bytu” o. A. Krapca), „Roczniki Filozoficzne” 12 (1964) nr 3, s. 99-103.

${ }^{22}$ Ch. H. Kahn, O czasowniku..., dz. cyt., s. 32. 
la - Filona Aleksandryjskiego, w którego pismach zachowały się najstarsze przykłady przedstawionego wyżej podejścia do problemu poznania Absolutu. Ważną postacią w wyłanianiu się problematyki istnienia był neoplatoński rzymski filozof Anicjusz Manliusz Sewerynus Boecjusz. Ten żyjący na przełomie V i VI wieku chrześcijański myśliciel w swoim dziele W jaki sposób substancje moga być dobre w tym, że sa, chociaż nie sa dobrami substancjalnymi ${ }^{23}$ stwierdza: „Czym innym jest bycie i to, czym rzecz jest. Samo bowiem bycie jeszcze nie jest, ale przyjąwszy formę bytu, jest i istnieje"24. Badacze wskazują, że jest to pierwsze wyraźne zaznaczenie różnicy między istotą a istnieniem w bycie konkretnym. Jerzy Gułkowski wskazuje, że już pierwsi komentatorzy, m.in. anonimowi autorzy glosy z IX wieku uważali, że Boecjusz w powyższym fragmencie dokonuje rozróżnienia między esse („byciem”), które utożsamia z Bogiem, a id quod est („tym, czym coś jest”), czyli bytami stworzonymi. To, co stworzone, dopiero poprzez uczestniczenie w byciu uzyskuje status czegoś realnego. Wspomniany traktat był przedmiotem wielu, nierzadko sprzecznych, interpretacji. Paweł Milcarek zauważa, że spór między Idzim Rzymianinem a Henrykiem z Gandawy, którego przedmiotem był charakter różnicy między istotą a istnieniem, tak naprawdę dotyczył tego, co kryje się za wprowadzonym przez Boecjusza rozróżnieniem na esse i id quod est $t^{25}$. Przeważnie myśl Boecjusza odczytuje się jako przykład systemu esencjalnego, czyli takiego, w którym byt pojmowany jest jako przede wszystkim niesprzeczna wewnętrznie treść, czyli istota. Chociaż można spotkać się również z egzystencjalnymi interpretacjami pism tego rzymskiego uczonego, czyli takimi odczytaniami, w których pierwszeństwo w strukturze bytu nadaje się istnieniu ${ }^{26}$. Takiego zabie-

${ }^{23}$ Zob. A. M. S. Boecjusz, W jaki sposób substancje moga być dobre w tym, że sa, chociaż nie sa dobrami substancjalnymi, w: A. M. S. Boecjusz, Traktaty teologiczne, tłum. A. Kijewska, Kęty 2007.

${ }^{24}$ A. M. S. Boecjusz, W jaki sposób substancje moga być dobre.., dz. cyt., s. 85.

${ }^{25}$ Zob. P. Milcarek, Od istoty do istnienia..., s. 427.

${ }^{26} \mathrm{Na}$ temat różnicy między metafizyką egzystencjalną i esencjalną zob. E. Morawiec, P. Mazanka, Metafizyka klasyczna..., dz. cyt.; E. Morawiec, Odkrycie egzystencjalnej..., dz. cyt. 
gu dokonuje Tomasz z Akwinu, a robi to m.in. po to, aby wzmocnić autorytetem Boecjusza swój sposób postrzegania bytu ${ }^{27}$.

W samej filozofii okresu hellenistycznego pojawiają się dwa pojęcia, które w jakimś stopniu mogą wyrażać to samo co pojęcie „istnienie”. Są to czasownik hyparchō i odpowiadający mu rzeczownik hyparxis, które w nowożytnym języku greckim oznaczają „istnienie”. Drugi czasownik natomiast to hypostēnai, z rzeczownikiem hypostasis, który z kolei odpowiada łacińskiemu pojęciu subsistere, a to powoduje, że jest bliski znaczeniowo czasownikowi exsistere. Mimo to Kahn ma wątpliwości, czy w sposobie użycia tych terminów można się doszukać takiego, które w jakiś sposób korespondowałoby z nowożytnym użyciem pojęcia „istnienie”:

Podejrzewam, że staranne studia pokazałyby, że w sposobie użycia nawet i tych greckich terminów nie odnajdziemy żadnego realnego odpowiednika naszego pojęcie istnienia. Jakkolwiek by było, owa późniejsza terminologia posługująca się słowami hyparxis i hypostasis nie odgrywa żadnej roli w Platońskim i Arystotelesowskim sformułowaniu ontologii $[\ldots]^{28}$.

Kahn podkreśla, że powodem, dla którego greckie postrzeganie bytu różni się od nowożytnego ujmowania istnienia, jest to, że między exsistere a einai mamy do czynienia z daleko idącą różnicą jeśli chodzi o własności obu pojęć. Łacińskiemu pojęciu dużo bliżej do greckiego gignesthai, czyli „stawać się”, „powstawać” ${ }^{29}$.Zdaniem współczesnego filozofa

${ }^{27}$ M. A. Krąpiec, Struktura..., dz. cyt.; S. Bafia, Komentarz św. Tomasza z Akwinu do "De hebdomadibus” $i$ „De Trinitate” Boecjusza. Dyskusja św. Tomasza z Akwinu zaugustynizmem, Kraków 1998.

${ }^{28}$ Ch. H. Kahn, Dlaczego w filozofii..., dz. cyt., s. 54.

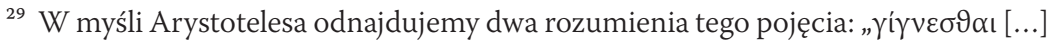
(1) «stawać się w sensie absolutnym» [...], co odnosi się wyłącznie do substancji [...]; (2) «stawać się czym» [...] czyli pod pewnym względem, kiedy już istniejący byt zmienia się pod względem wielkości, jakości lub jakieś innej przypadłości [...]. Mając na uwadze źródło powstawania, Arystoteles konkluduje, iż «rzeczy powstają albo przez sztu- 
sama etymologia czasownika exsistentia wskazuje na jego dynamiczny charakter: „[...] etymologicznie exsistere sugeruje występowanie czy też czynienie kroku naprzód, zaistnienie, wynurzenie się z mrocznego tła na światło dzienne"30. Jego zdaniem tezę tę potwierdza przedrostek ex-, który związany jest z zakończeniem jakiegoś procesu. Kontynuując swoje rozważania filologiczne, Kahn stwierdza, że existentia pełni w pewnym sensie funkcję perfectum dla gignesthai. Wyraża stan, który stanowi zwieńczenie procesu zaistnienia. Zdaniem tego badacza początkowo to właśnie zastosowanie czasownika w perfectum pozwalało osiągnąć sens egzystencjalny czasownika. Rzecz istniejąca ujmowana była „jako to, co zaistniało"31.

Do rozwoju językowych konotacji terminu exsistentia doszło na skutek zetknięcia się myśli greckiej z judeochrześcijańską teorią creatio ex nihilo oraz rozwinięcia idei różnicy pomiędzy istotą a istnieniem. Kahn stwierdza, że w perspektywie średniowiecznych rozważań nad naturą bytów przygodnych, koncepcja, że są one stworzone z niczego wolą Boga, pociąga za sobą fakt, że ich istnienie jest czymś innym niż ich istota. To właśnie przeświadczenie o radykalnej przygodności, jak określa Wojtysiak przekonanie, że wszechświat w ogóle mógłby nie istnieć, spowodowało, że owe językowe konotacje omawianego terminu zostały pogłębione. Dużą rolę odegrali w tym procesie również myśliciele muzułmańscy. Według Kahna w ich rozważaniach dotyczących tego zagadnienia istotne było oddawanie greckich pojęć to on i to einai poprzez bierną formę czasownika o rdzeniu $w-\check{g}-d$, który oznacza „znajdować”. To z tego rdzenia wywodzi się arabskie słowo na oznaczenie istnienia, czyli wuğūd. Pojęcie to niesie za sobą znaczenie zarówno egzystencjalne, jak również lokacyjne. Jerzy Łacina w swoim słowniku arabsko-polskim wymienia następujące współczesne znaczenia po-

kę, albo z natury, albo przez przypadek, albo samoczynnie»". K. Nerecki, Stownik terminów Arystotelesowych, w: Arystoteles, Dzieła wszystkie, t. 7, tłum. K. Leśniak, Warszawa 2003, s. 33.

${ }^{30}$ Ch. H. Kahn, O czasowniku..., dz. cyt., s. 23.

${ }^{31}$ Ch. H. Kahn, O czasowniku..., dz. cyt., s. 23. 
wyższego terminu: „wuǧūd 1) istnienie; byt 2) przebywanie; obecność; znajdowanie się; istnienie" ${ }^{32}$. Natomiast w słowniku autorstwa Janusza Daneckiego i Jolanty Kozłowskiej zostają podane następujące możliwości tłumaczenia tego słowa: „wuǧūd 1. istnienie. egzystencja 2. odkrycie, odnalezienie 3. pobyt, przebywanie" ${ }^{33}$. Jak widać, również tutaj podkreśla się obok znaczenia egzystencjalnego również sens lokacyjny, który wyrażony jest drugim i trzecim z wyróżnionych przez polskich arabistów znaczeń tego terminu. „Odkrycie”, które pojawia się w drugim z wymienionych sensów, ma charakter przestrzenny i odnosi się do odkrywania, odnajdowania czegoś właśnie w przestrzeni.

Znaczenie myśli muzułmańskiej w procesie kształtowania się i rozwoju problemu istnienia nie ulega wątpliwości. To tacy myśliciele jak Awicenna czy Awerroes wnieśli bardzo dużo do późniejszych rozważań łacinników odnośnie do zagadnienia relacji między istotą a istnieniem. Awicenna uchodzi za pierwszego filozofa, który uznał, że między tymi dwoma składnikami strukturalnymi bytu mamy do czynienia z różnicą realną. Stanowiło to istotne źródło inspiracji dla Tomasza z Akwinu, który zaproponował w pełni egzystencjalną koncepcję bytu. W jej kształtowaniu odegrała rolę również polemika Awerroesa z Awicenną. Awerroes odrzucał tezę swojego adwersarza, że istnienie jest tylko przypadłością istoty. Tomasz, przyjmując, że istota i istnienie różnią się realnie, jednocześnie uznał, że istnienie nie jest przypadłością, ale aktem bytu.

Rozważania Kahna wpisują się w dominujący sposób postrzegania rozwoju metafizyki klasycznej. Podobnie jak wielu badaczy twierdzi on, że problem istnienia wymykał się antycznym, jednak swoje wnioski formułuje na podstawie analizy języka, którym posługiwali się Grecy. Stwierdza, że to sam sposób, w jaki Hellenowie mówili o świecie, utrudniał im - jeśli całkowicie nie uniemożliwiał - uświadomienie sobie problematyczności, która związana jest z pojęciem „istnienie”. I cho-

\footnotetext{
32 J. Łacina, Słownik arabsko-polski, Poznań 1997, s. 922.

${ }^{33}$ J. Danecki, J. Kozłowska, Słownik arabsko-polski, Warszawa 2010, s. 785.
} 
ciaż, jak twierdzi Piotr Cyciura ${ }^{34}$, zagadnienie istnienia występuje nie wprost w myśli Arystotelesa i na gruncie arystotelizmu można go rozwiązać, to sam Stagiryta, jak i inni antyczni filozofowie, nie podejmował tej kwestii jako istotnej z filozoficznego punktu widzenia. Takie podejście powodowało, że filozofia antyczna miała zdecydowanie esencjalny charakter, a egzystencjalna wersja metafizyki klasycznej wykształciła się dopiero w okresie średniowiecza. Jak dowodzi Kahn, jedną z głównych przyczyn tego stanu rzeczy był język i sposób, w jaki Grecy posługiwali się takimi kluczowymi pojęciami jak właśnie einai.

\section{QUESTION OF EXISTENCE IN GREEK PHILOSOPHY - CHARLES H. KAHN'S APPROACH}

SUMMARY

Scholars agree that question of existence was ignored by the ancient Greeks. The main cause of such a state was the way that the ancients perceived the world. We can found this imgage not only in their mythology, but also in their philosophy. Jacek Wojtysiak claims, for antic Hellenes the world was relatively contingent, which means that for them anything that was, was not something necessary, because the whole reality was constantly changing. Therefore, the universe and its laws could receive different form that they have now. But the ancients didn't perceived reality as radically contingent, which means that they received the universe as eternal and it was impossible that it would not exist. This is the way Greeks concentrated on the question of nature of the reality, what was it basic substance, and what decide that the universe was what it was.

Charles H. Kahn's considerations are important in the study of the ancient conception of being and existence. Basing on the analysis of language of ancient Greeks, he answers the question why they didn't considered the question of existence. Kahn claims that for ancients the main issue in Greek's theory

${ }^{34}$ Zob. P. Cyciura, Problem istnienia w filozofii Arystotelesa. Interpretacja tomistyczna, Warszawa 2009. 
of being was not the question of the existence, but truthfulness meaning of the verb einai. This linguistic investigations are useful because, as he claims, the way how we are perceiving the reality depends on language we use. It also applies to ontological consideration.

\section{KEYWORDS}

essence, existence, being, Greek philosophy, Kahn

\section{BIBLIOGRAFIA}

Adamczyk S., Arystotelesowo-tomistyczna koncepcja formy substancjalnej, „Roczniki Filozoficzne” 12 (1964) nr 3, s. 5-15.

Adamczyk S., Różnica między istota a istnieniem substancjalnym w nauce Arystotelesa, „Roczniki Filozoficzne” 7 (1959) nr 1, s. 103-127.

Adamczyk S., Struktura bytu przygodnego wedtug Arystotelesa (uwagi na marginesie „Struktury bytu” o. A. Krapca), „Roczniki Filozoficzne” 12 (1964) nr 3, s. 99-103.

Arystoteles, Dzieła wszystkie, t. 1, tłum. K. Leśniak, Warszawa 2003.

Arystoteles, Dzieła wszystkie, t. 2, tłum. K. Leśniak i in., Warszawa 2003.

Arystoteles, Dzieła wszystkie, t. 3, tłum. P. Siwek, Warszawa 2003

Arystoteles, Dzieła wszystkie, t. 7, Warszawa 2003.

Averroes (Ibn Rushd), Tahafut al-Tahafut (The Incoherence of the Incoherence),

transl. S. van Den Bergh, http://www.newbanner.com/Philosophy/IbnRushd/Tahafut_al-Tahafut_en.pdf (o3.11.2014).

Averroes, Averroes' Middle Commentaries on Aristotle's "Categories” and „De

Interpretatione", transl. Ch. E. Butterworth, South Bend, Indiana 1998.

Averroes, Averroes' Questions in Physics, transl. H. T. Goldstein, DordrechtBoston-London 1991.

Averroes, De Substantia Orbis, transl. A. Hyman, Cambridge, Massachusetts Jerozolima 1986.

Averroës, Decisive Treaties, Epistle Dedicatory, transl. Ch. E. Butterworth, Pravo, Utah 2008.

Averroes, On Aristotle's „De Generatione et Coruptione”. Middle Commentary and Epitom, transl. S. Kurland, Cambridge, Massachusetts 1958. 
Averroes, On Aristotle's „Metaphysics”. An Annotated Translation of So-called „Epitome”, transl. R. Arnzen, Berlin-Newy York 2010.

Avicenna, On Theology, transl. A. J. Aeberry, Kitab al-Islamiyyah, Dubai (brak daty wydania).

Avicenna, The Metaphysics of The Healing, transl. M. E. Marmura, Pravo, Utah 2005.

Avicenna, The Physics of The Healing, ks. 1 i 2, transl. J. McGinnis, Pravo, Utah 2009.

Avicenna, The Physics of The Healing, ks. 3 i 4, tłum. J. McGinnis, Pravo, Utah 2009.

Awicenna, Księga wiedzy, tłum. B. Składanek, Warszawa 2010.

Awicenna, Metafizyka: ze zbioru „Księga wiedzy”, tłum. H. Górska i in., Warszawa 1973.

Bafia S., Komentarz św. Tomasza z Akwinu do „De hebdomadibus" $i$ „De Trinitate” Boecjusza. Dyskusja św. Tomasza z Akwinu z augustynizmem, Kraków 1998. Boecjusz A. M. S., Traktaty teologiczne, tłum. A. Kijewska, R. Bielak, Kęty 2007. Copleston F., Historia filozofii, t. 1, tłum. H. Bednarek, Warszawa 1998.

Copleston F., Historia filozofii, t. 2, tłum. S. Zalewski, Warszawa 2000.

Cyciura P., Problem istnienia w filozofii Arystotelesa. Interpretacja tomistyczna, Warszawa 2009.

Danecki J.; Kozłowska J., Słownik arabsko-polski, Warszawa 2010.

Diogenes Laertios, Żywoty i poglady stynnych filozofów, tłum. I. Krońska i in., Warszawa 2004.

Gilson É., Byt i istota, tłum. D. Eska, J. Nowak, Warszawa 2006.

Heraklit, Fragmenty (O naturze), tłum. M. Wesoły, „Studia Filozoficzne” 1989 nr 7-8, s. 40-47.

Hezjod, Narodzony bogów (Theogonia), Prace i dni, Tarcza, tłum. J. Łanowski, Warszawa 1999.

Ibn Rushd's Metaphysics. A Translation with Introduction of Ibn Ruszd's Commentary on Aristotle's Metaphysic, Book Läm, tłum. Ch. Genequand, Leiden 1986.

Kahn Ch. H., Język i ontologia, tłum. B. Żukowski, Kęty 2008.

Kokoć D., Creatio ex nihilo a filozoficzne wyodrębnienie problematyki istnienia, "Przegląd Religioznawczy” 2014 nr 1 (251), s. 55-64. 
Krąpiec M. A., Byt $i$ istota. Św. Tomasz „De ente et essentia” przekład $i$ komentarz, Lublin 2001.

Krąpiec M. A., Struktura bytu. Charakterystyczne elementy systemu Arystotelesa $i$ Tomasza $z$ Akwinu, Lublin 2000.

Łacina J., Stownik arabsko-polski, Poznań 1997.

Milcarek P., Od istoty do istnienia. Tworzenie się metafizyki egzystencjalnej wewnątrz łacińskiej tradycji filozofii chrześcijańskiej, Warszawa 2008.

Morawiec E., Mazanka P., Metafizyka klasyczna wersji egzystencjalnej. Podstawowe zagadnienia $z$ metafizyki, Warszawa 2006.

Morawiec E., Odkrycie egzystencjalnej wersji metafizyki klasycznej. Studium historyczno-analityczne, Warszawa 2004.

Parmenides, Fragmenty „O naturze”, tłum. M. Wesoły, w: Człowiek i społeczeństwo w refleksji filozoficznej, red. G. Kotlarski, R. Kozłowski, Poznań 1992.

Platon, Państwo, t. 1, tłum. W. Witwicki, Warszawa 1999.

Platon, Państwo, t. 2, tłum. W. Witwicki, Warszawa 1999.

Platon, Uczta, tłum. W. Witwicki, Warszawa 1999.

Reale G., Historia filozofii starożytnej, t. 1, tłum. E. I. Zieliński, Lublin 2000.

Reale G., Historia filozofii starożytnej, t. 2, tłum. E. I. Zieliński, Lublin 2001.

Reale G., Historia filozofii starożytnej, t. 4, tłum. E. I. Zieliński, Lublin 1999.

Reale G., Historia filozofii starożytnej, t. 5, tłum. E. I. Zieliński, Lublin 2008.

Studia wokót problematyki esse (Tomasz z Akwinu i Boecjusz), red. B. Bejze, Warszawa 1976.

Tomasz z Akwinu, Byt i istota, tłum. W. Seńko, Kęty 2009.

Tomasz z Akwinu, Dysputy problemowe „O prawdzie”, tłum. A. Białek, Lublin 2001.

Tomasz z Akwinu, Dzieła wybrane, tłum. J. Salij, Poznań 1984.

Tomasz z Akwinu, Komentarz do „Księgi o przyczynach”, tłum. A. Rosłan, Warszawa 2010.

Tomasz z Akwinu, O wieczności świata, tłum. A. Pakulniewicz, Warszawa 2003. Tomasz z Akwinu, Summa contra gentiles. Prawda wiary chrześcijańskiej w dyskusji z poganami, innowiercami i błądzacymi, t. I, tłum. Z. Włodek, W. Zega, Poznań 2003. 
Tomasz z Akwinu, Summa contra gentiles. Prawda wiary chrześcijańskiej w dyskusji z poganami, innowiercami i bładzacymi, t. 2, tłum. Z. Włodek, W. Zega, Poznań 2007.

Tomasz z Akwinu, Summa contra gentiles. Prawda wiary chrześcijańskiej w dyskusji z poganami, innowiercami i bładzacymi, t. 3, tłum. Z. Włodek, W. Zega, Poznań 2009.

Wojtysiak J., O stowie BYĆ. Z teorii wyrażeń egzystencjalnych $i$ ich filozoficznego zastosowania, Lublin 2005.

Wojtysiak J., Starożytne poczatki problematyki istnienia, „Kwartalnik Filozoficzny" (2001) nr 1 (29), s. 5-27. 